\title{
Italian Studies and the Digital
}

DOI:

10.1080/00751634.2020.1744867

\section{Document Version}

Accepted author manuscript

Link to publication record in Manchester Research Explorer

\section{Citation for published version (APA):}

Armstrong, G., \& Patti, E. (2020). Italian Studies and the Digital. Italian Studies, 1-15.

https://doi.org/10.1080/00751634.2020.1744867

\section{Published in:}

Italian Studies

\section{Citing this paper}

Please note that where the full-text provided on Manchester Research Explorer is the Author Accepted Manuscript or Proof version this may differ from the final Published version. If citing, it is advised that you check and use the publisher's definitive version.

\section{General rights}

Copyright and moral rights for the publications made accessible in the Research Explorer are retained by the authors and/or other copyright owners and it is a condition of accessing publications that users recognise and abide by the legal requirements associated with these rights.

\section{Takedown policy}

If you believe that this document breaches copyright please refer to the University of Manchester's Takedown Procedures [http://man.ac.uk/04Y6Bo] or contact uml.scholarlycommunications@manchester.ac.uk providing relevant details, so we can investigate your claim.

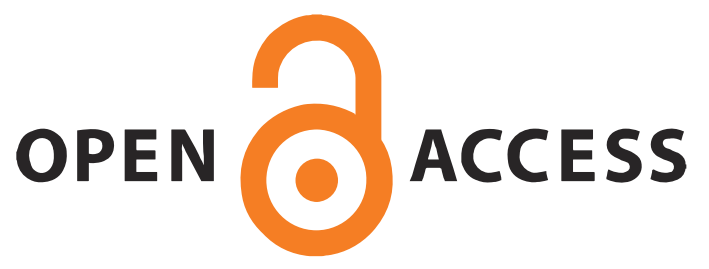




\title{
Contact details
}

Dr Guyda Armstrong

Department of Italian, Modern Languages and Cultures,

School of Arts, Languages, and Cultures

University of Manchester

Manchester

M13 9PL

Email: guyda.armstrong@manchester.ac.uk

Dr Emanuela Patti

124, International Building

School of Modern Languages, Literatures and Cultures

Royal Holloway

Egham Hill TW20 0EX

Surrey

Email: emanuela.patti@rhul.ac.uk

To cite this article: Guyda Armstrong \& Emanuela Patti, 'Italian Studies and the Digital', Italian

Studies, 75. 2 (2020): DOI: 10.1080/00751634.2020.1744867

To link to this article: https://doi.org/10.1080/00751634.2020.1744867

\section{Italian Studies and the Digital}

\begin{abstract}
This article reflects on the history and futures of the 'digital' - that is, what might be termed 'digital humanities' and 'digital cultures' in relation to Italian Studies. We provide an overview of some of the major achievements and trends in the field, and show how Italian Studies scholars have engaged with the technological and epistemological developments of the digital age in terms of theories, methods, and approaches to Italian culture. We concentrate, in particular, on Italian literature, examining first the research milestones of 'umanistica digitale'. The second part of the article analyses the phenomenon of Italian literature and criticism 3.0 and looks at the recently developed fields of electronic literature and transmedia storytelling.
\end{abstract}

\section{Keywords}

Digital humanities, digital cultures, electronic literature, digital arts, media studies

\section{Funding details}

This work has been partly supported by the AHRC under the grant Interdisciplinary Italy 19002020: interart/intermedia (ref. AH/M008819/1)

\section{Biographical notes}

Dr Guyda Armstrong is Senior Lecturer in Italian and Director of the Centre for Digital Humanities at the University of Manchester.

Dr Emanuela Patti is Honorary Research Associate in the School of Modern Languages, Literatures and Cultures at Royal Holloway, University of London. 


\section{Italian Studies and the digital**}

Guyda Armstrong and Emanuela Patti

At the end of the second decade of the twenty-first century, networked digital technologies and devices are profoundly embedded in our everyday lives, directly mediating our access to information and culture, and acting on us as they in turn shape our social, cultural and working practices and interactions. This, along with the much-discussed computational turn in the humanities raises important questions about how digital technologies have transformed, and are transforming, the interdisciplinary field of Italian Studies. Our discipline is still hybrid, in that we continue to mix 'traditional' analogue and 'new' digital practices to acquire knowledge and develop skills, but the presence of the 'digital' in everything we do is significantly changing the way we understand literacies and pedagogy; publishing, research materials, our objects of study, and the very notion of 'culture'. ${ }^{1}$ Digital databases of artworks, texts, scholarly publications, corpora and reference resources, produced within the academy and or by corporate commercial providers, are ubiquitous in our lives as researchers, while computational techniques such as statistical analysis, text mining, data visualisation, culturomics, and management metrics can be applied to these to produce new findings at hitherto unimaginable scales and granularity. ${ }^{2}$ Even more significantly, the electronic tools and technologies which shape our working and social lives have now been recognised themselves as expressive forms and objects of study. Digital technologies, social media, mobile devices and the techno-cultural processes of digital convergence have also had a remarkable impact on the way we create and circulate narratives, imaginaries, and aesthetic experiences. They have transformed social and cultural habits, spread grassroots and bottom-up collaborative practices across a broad range of fields, and offered opportunities, as well as challenges, for artists, audiences, and the cultural and creative industries.

\footnotetext{
* The authors would like to thank David Robey and Massimo Riva for their invaluable help on the history of humanities computing in Italian studies.

${ }^{1}$ On this see David M. Berry and Anders Fagerjord, Digital Humanities: Knowledge and Critique in a Digital Age (Cambridge: Polity Press, 2017), pp. 1-2. Paul Spence and Renata Brandao's 2019 report for the AHRC-funded Open World Research Initiative, Attitudes towards Digital Culture \& Technology in the Modern Languages (2019), notes that digital tools, including apps and social media platforms, such as Duolingo, Memrise, Wordreference, Skype, Youtube, and Twitter, have become an integral part of teaching languages; digital tools have facilitated multilingual and multicultural learning; they make authentic content such as TV and radio programmes and interviews more accessible; they allow more independent forms of self-study; they encourage students and teachers to develop new forms of academic writing and presentation through intermedia genres such as blogs and video-essays; they provide new immersive experiences in the language and culture through virtual and augmented reality apps. Unfortunately, for reasons of space, we are not able to cover the topic of digitally mediated language learning initiatives in Italian Studies, which has historically been one of the most successful areas of digital engagement in the discipline area. We concentrate, instead, on digital technologies and methods in relation to the main subdisciplines of Italian Studies research, such as literature, history, and cinema.
}

${ }^{2}$ Berry and Fagerjord, p. 9. 
In Italy and within the Italian diaspora, a rich variety of new digital genres and cultural phenomena have developed at the intersection between different arts, media and communication practices, such as lit-blogs, visual novels, interactive films, web series, animation and digital arts, whose aesthetics, textuality, and the dynamics between authors and audiences require new critical tools. Many of today's cultural practices are in fact situated at the intersection between different arts, media, digital communication and social practices, yet these currently do not have anywhere near the same prominence in Italian Studies research as do objects of study in other contemporary or historic media forms. Critical approaches such as philology, cultural studies, reader-response, and semiotics do not seem to fully address, individually, new digitally-mediated forms of storytelling, intermedia representations and transmedia practices. Likewise, computational approaches and methods for Italian Studies research have been used for at least four decades at the time of writing, yet these have still not broken through into the scholarly mainstream.

The premise of this Special Issue of Italian Studies therefore offers us the opportunity to reflect on the history and futures of the 'digital' — that is, what might be termed 'digital humanities' and 'digital cultures' — in relation to Italian Studies. ${ }^{3}$ We provide an overview of some of the major achievements and trends in the field, and show how Italian Studies has engaged with the technological and epistemological developments of the digital age in terms of theories, methods, and approaches. In this way we aim to offer a new perspective on what is perhaps a lesser fully understood aspect of our discipline, and some thoughts on what it could potentially be in the future. While the focus of this Special Issue is to reflect on Italian Studies in the UK and Ireland, our focus on the digital naturally implicates much work done beyond our territories, mostly in Italy and in the USA; just as Italian Studies is now recognised as a transnational and multi-centred subject area, so the 'digital' transcends national territories and conventional disciplinary boundaries, and so we take stock of the wider contributions to digital humanities, digital culture practices, theory and criticism within and beyond our subject association. In this way, we align ourselves with recent critical debates on the relationship between digital humanities (DH) and modern languages (ML), in order to discuss what forms of collaboration and future directions of research could develop within and across digital humanities, digital culture studies, and digital arts. As various scholars have argued, we have entered a new phase of digital humanities in which we do not only apply tools and techniques of digital media to bear on traditional humanistic questions, but also bring humanistic

\footnotetext{
${ }^{3}$ A special Digital Humanities issue of the journal Italian Culture was published on 30 March 2020, unfortunately too late for us to take account of it in this essay. The issue includes Crystal Hall's introductory article, 'Digital Humanities and Italian Studies: Intersections and Oppositions', Italian Culture, 37.2 (2019), 97-115, which addresses many of the themes we explore here, plus seven further articles on scholarly projects at the intersection of Digital Humanities and Italian Studies, by Massimo Lollini, Isabella Magni, Brendan Hennessey, Allison Cooper, Daniel Leisawitz, Serena Ferrando, and Crystal Hall.
} 
modes of inquiry to bear on digital media, and their inherent politics. ${ }^{4}$ This perspective sets the ground for a 'critical or reflexive interdisciplinarity' in digital humanities, to which scholars in modern languages can significantly contribute with their knowledge of the national and area studies paradigms, as Claire Taylor and Thea Pitman have argued. ${ }^{5}$ Similarly, the study of digital culture and digital creativity has become crucially relevant for modern languages as humanities disciplines, because it investigates, among other topics, the role that the Internet, new media and digital technologies play in contemporary societies, cultures, and the arts. While the relationship between digital culture studies and modern languages is still relatively under-theorised, it has become increasingly urgent to critically explore the interface between new media technologies and Italian cultural and artistic practices. ${ }^{6}$ We therefore conclude by considering where these two areas of study, digital humanities and digital culture studies, can meet in Italian Studies, considering the ways in which Italian Studies might intersect with new computational research trends such as machine learning, data visualisation (both quantitative and representational, such as heritage imaging and mapping), and integrate further with UK/ROI institutional entities in the digital humanities, and likewise, how Italian Studies can contribute its unique disciplinarily-inflected perspective and that of the modern languages to urgent debates about the uses of the humanities in an increasingly digital, corporate world.

\section{Digital Humanities and Italian Studies}

Digital humanities, or humanities computing as it was previously known, is generally held to have begun with the computational linguistics experiments of the 1940s, (with a particular Italian dimension, as we shall see), and it gained increasing prominence and academic traction in line with

\footnotetext{
${ }^{4}$ One early exploration of this can be found in Kathleen Fitzpatrick, 'The Humanities, Done Digitally', in Debates in the Digital Humanities, ed. by Matthew K. Gold, (Minneapolis: University of Minnesota Press, 2012), pp. 12-15, and $<$ https://dhdebates.gc.cuny.edu/read/untitled-88c11800-9446-469b-a3be-3fdb36bfbd1e/section/65e208fc-a5e6-479f9a47-d51cd9c35e84\#ch02>. [all online references in this article were accessed on 1 February 2020].

${ }^{5}$ Julie Thompson Klein, Interdisciplining Digital Humanities: Boundary Work in an Emerging Field (Ann Arbor: University of Michigan Press, 2015), discussed in Thea Pitman and Claire Taylor, 'Where's the ML in DH? And where's the DH in ML? The Relationship between the Modern Languages and Digital Humanities, and an Argument for a Critical DH', DHQ: Digital Humanities Quarterly, 11.1 (2017), paragraphs 5-6 < http://www.digitalhumanities.org/dhq/vol/11/1/000287/000287.html >.

${ }^{6}$ The surprisingly lack of research into national cybercultures may be due to the fact that digital culture and media require a theoretical and methodological approach that goes well beyond the usual methods of textual analysis usually applied to literary and film studies. Moreover, the study of Italian cultural life in schools and universities is still strongly associated with the literary and film traditions. It is clear that the wide variety of hybrid cultural and artistic forms that have resulted from digital convergence urgently need new theories and methods, to be developed at the intersection between arts, cultural studies and media studies.
} 
the expansion of mass networked computing during the decades which followed. ${ }^{7}$ Computational approaches to literary, linguistic, and historical study have therefore long been with us, and have now been augmented by newer data visualisation modes such as mapping and network analysis software, and the mass digitisation of physical cultural objects (manuscripts and rare books; archives, and artworks, to name just a few). None the less, 'digital humanities' remains a relatively minor concern in terms of research and activity in Italian Studies, despite the explicit efforts of institutions and national funding bodies to cultivate it and place it at the centre of humanistic pursuits; a trend which is often linked to scientism and the increasingly utilitarian directives for the functions of higher education.

The history of DH from the Italian Studies perspective is one entangled with modern languages, national language identities, and the traditional hierarchies of power, race and gender. The recent attention to a global (or supposedly global) DH has exposed these tensions to scholarly attention, and this is therefore a timely moment to reflect on the history of DH in relation to Italy and Italian studies, as it is practiced in the UK and Anglophone scholarly world, and in its interactions between and beyond geographical and disciplinary boundaries. ${ }^{8}$ In recent years, there have been a number of interventions which aim to construct both a particular Italian history of digital humanities, or 'Umanistica digitale', and to assess its place in Italian studies, or Italianistica; the situation is complicated by the fact that these interventions and their perspectives are naturally governed by their emergence from multiple locales and the particular positionality of their authors. One of these locales is Italy itself, through the contributions of Italy-based scholars such as Fabio Ciotti and Domenico Fiormonte, writing from within the nationally-conceptualised, geographicallysituated Italian scholarly humanities community, with its own national digital humanities association, the Associazione per l'Informatica Umanistica e la Cultura Digitale (AIUCD). ${ }^{9}$ Beyond this is the distributed transnational discipline of 'Italian Studies', which in terms of DH was historically largely shaped by the major contributions of Italianist (and often Italian) scholars based for the most part in the USA. The digital humanities projects emerging from Italianists based in

\footnotetext{
${ }^{7}$ The term 'digital humanities' is much contested, but we follow Berry and Fagerjord here in using it, since 'as a term it helpfully situates humanities research that is self-consciously digital in its orientation' (p. 1).

${ }^{8}$ On this see Roopika Risam, New Digital Worlds: Postcolonial Digital Humanities in Theory, Praxis, and Pedagogy (Evanston, IL: Northwestern University Press, 2019).

${ }^{9}$ The AIUCD was founded in 2011, and its mission statement outlines its engagement with digital humanities and digital cultures in the widest terms: 'The Associazione per l'Informatica Umanistica e la Cultura Digitale was established in Florence on March 25, 2011. The name chosen for the Association highlights the choice to combine the traditionally used term of Humanistic Informatics with Digital Culture, to openly encompass a wider scope than that of the disciplinary sectors, which may include all stakeholders, including cultural institutions (archives, libraries and museums) that play a key role in research and teaching in the humanities field.': $<$ http://aiucd2019.uniud.it $>$.
} 
Ireland and the UK have generally been smaller in scale and markedly fewer than those which have originated elsewhere, but we can still evidence several decades of computationally-mediated research and outputs (some of which have not hitherto been considered 'digital humanities' and described as such), to which have been added in recent years increasing activities in the field of Italian electronic arts and digital cultures.

Research in digital humanities, by its very nature, is an inherently collaborative and multidisciplinary exercise, whose projects require the input of many different individuals, each expert in different technical and subject domains, and thus in some ways it is specious to think of it in specifically subject-oriented terms. There is of course a degree of mobility and collaboration of individuals working between different general geographical territories within and outside Italy, but we should also note that much digital humanities activity on 'Italian' subjects likewise takes place outside University languages departments (for example, in history, art history, archaeology or via major heritage infrastructure projects), and many of the agents working on these projects such as computer scientists, software engineers, web designers, and so on, do not identify as Italianists, or even primarily with a humanities affiliation. This may be one of the contributing factors as to why, historically, Italian Studies in the UK, at least, has not much engaged with wider debates and activities around the digital humanities, a situation which is also true more broadly for modern languages as a whole. This situation is now changing rapidly as more UK-based ML and Italian Studies researchers become involved with the formal institutions and working groups of the UK digital humanities landscape, such as the group working towards a new Digital Humanities subject association, the Alan Turing Institute's Digital Humanities and Data Science research group, and the Software Sustainability Institute.

A recent report to the Software Sustainability Institute on the digital humanities landscape in the UK captures the profound heterogeneity and diversity of $\mathrm{DH}$ in its institutional locations and practices:

DH practitioners' work is both interdisciplinary and a sub-discipline of humanities and related fields. Their work intersects with fields, such as heritage science; digital methods within history, classics, literary studies and archaeology; modern languages, linguistics, literary and textual studies; art history; media archaeology; science and technology studies; digital musicology; digital cultural heritage, and creative computing. Practitioners may 
ordinarily profess these disciplines, while intermittently practising within the DH space, or identify primarily as working in $\mathrm{DH} .^{10}$

In this respect, there are clear affinities with the modern languages disciplines themselves, as they seek to move beyond the traditional organisational structures of the nation-state subject areas, now conceptualised as a broadened area of study which embraces interdisciplinary and intermedial perspectives, often transnational in reach. ${ }^{11}$ Italianists might undertake research in any of the above areas, and/or research on digital subjects, and/or deploy digital methods and tools 'intermittently' as desired. This newer formulation of $\mathrm{DH}$ as what digital humanists 'do', rather than what the discipline 'is', is helpful as we take stock of its achievements and, more importantly, its potential to shape Italian Studies in the future. ${ }^{12}$

The question of a specifically 'Italian' digital humanities has most recently been explored by Fabio Ciotti in several contributions, including the position piece written for the launch issue of the new Italian digital humanities journal Umanistica digitale in 2017, and his conference contribution for the DH2018 conference in Mexico City, 'Dall'Informatica umanistica alle Digital Humanities: Per una storia concettuale delle DH in Italia'. ${ }^{13}$ In the journal, Ciotti outlines the decision by the AIUCD to institute a new multilingual, Italy-based open-access online journal as the next stage in articulating a specifically Italian perspective on DH, while still locating itself firmly within the global networks of digital humanities and digital cultural studies. ${ }^{14}$ Ciotti argues for the necessity for a specifically Italian DH, growing out of the Italian context, 'che raccoglie e sintetizza una tradizione scientifica di grande importanza', that is, the tradition of the foundational Italian computational linguist Father Roberto Busa, and the seminal contributions of the academics of the so-called 'scuola romana'. ${ }^{15}$ Italian digital humanities should therefore be centred, as it has been

\footnotetext{
10 'Sustaining the Digital Humanities', draft report to the Software Sustainability Institute, authored by the members of the panel at the SSI event at the Oxford eResearch Centre on 21 June 2018.

${ }^{11}$ On this, see Clodagh Brook, Florian Mussgnug, and Giuliana Pieri, 'Italian Studies: An Interdisciplinary Perspective', Italian Studies, 72.4 (2017), 380-92 (p. 380).

${ }^{12}$ The SSI report observes that 'Variously (and sometimes precariously) institutionalised, it might be best characterised as a shifting community of practice in which participants hold diverse affiliations: $\mathrm{DH}$ arises in part as a debate about the composition and goals of that community'.

${ }^{13}$ Fabio Ciotti, 'Una nuova avventura', Umanistica digitale, 1 (2017), 1-3; 'Dall'Informatica umanistica alle Digital Humanities: Per una storia concettuale delle DH in Italia', <https://dh2018.adho.org/dallinformatica-umanistica-alledigital-humanities-per-una-storia-concettuale-delle-dh-in-italia/ $>$.

${ }^{14}$ Ciotti notes that the AIUCD was the first of the national DH associations to emerge in Europe, and the first to affiliate formally with the European Association for Digital Humanities (EADH), 'Una nuova avventura', p. 2.

${ }^{15}$ The foundation of the digital humanities is often traced back to the pioneering computational linguistics collaboration between Father Roberto Busa and the American computing company IBM which began in 1949, to produce an electronic concordance of the works of Thomas Aquinas, the Index Thomisticus. This primal — and Italian — scene of humanities computing is foundational not just to digital humanities as a whole but to specifically Italian conceptualisations of it, and looms large in the auto-narratives of the discipline.
} 
historically, in methodological and scientific questions. His DH2018 intervention explicitly seeks to counteract the anglosphere's dominance of the field of DH by writing back the specific and particular achievements of the historic Italian contribution to $\mathrm{DH}$. Even the Italian name for humanities computing, 'l'informatica umanistica', stresses the privileging of the computational, by contrast with the terminology used elsewhere in the kaleidoscope of differently understood and differently expressed digital humanities. Ciotti argues that:

ciò che caraterizza questa esperienza [i.e. the Italian tradition] [...] è il rifiuto di una visione strumentale dell'informatica nelle discipline umanistiche (che era allora già abbastanza diffusa se non predominante nelle pur aurorali sperimentazioni a livello internazionale) e la netta predilezione per un approccio teorico e epistemologico. L'informatica viene intesa non come ingegneria ma come scienza teorica della rappresentazione ed elaborazione (automatica) dell'informazione, e su questo terreno è evidente la convergenza con le scienze umane. $^{16}$

But for Ciotti, the critical point is that, to date, the wider field of digital humanities has not yet given its due to the particular and long-standing contributions of Italy:

Resta il fatto che diversi decenni di sperimentazioni e di elaborazione tecnica hanno una visibilità globale assai scarsa. Senza dubbio la barriera linguistica ha constituito un ostacolo molto arduo da superare per ottenere il dovuto riconoscimento. Ma la questione del multilinguismo e del multiculturalismo nella comunità globale delle Digital Humanities è anche e soprattutto un problema di macro e microfisica dei poteri. Anche per questo occorre raccontare le nostre storie.

We will return to the topic of a global digital humanities and 'Italian Studies' DH within it in the last part of this article.

Anglosphere 'Italian Studies' digital humanities intersects in various moments and spaces with the national digital humanities landscapes of the countries in which it is conducted, and with Italy and other countries via the Italian and Italianist scholarly diaspora. Strikingly (and perhaps not surprisingly), the first major US-based IS digital humanities projects were led by premodern scholars working out of Italian departments in prestigious R1 research universities, primarily in the Ivy League. Their projects centred to a remarkable degree on the figures of the tre corone, with Dante predominating by a huge margin. These flagship early-adopter initiatives included projects such as the Dartmouth Dante Project; ${ }^{17}$ the World of Dante at the University of Virginia; ${ }^{18}$

\footnotetext{
${ }^{16}$ Ciotti, 'Per una storia concettuale'.

${ }^{17}$ Led by Robert Hollander and launched publicly in 1988: < https://dante.dartmouth.edu/about.php>.

${ }^{18}$ Led by Deborah Parker, launched 1996: < http://www.worldofdante.org/about.html>.
} 
Columbia University's Digital Dante ${ }^{19}$ the Princeton Dante Project; ${ }^{20}$ the Decameron Web at Brown University; ${ }^{21}$ and, some time later, the Oregon Petrarch Open Book, ${ }^{22}$ and the Petrarchive. ${ }^{23}$ We should also mention here the important work of Jeffrey Schnapp, an Italianist pioneer in the fields of digital humanities and experimental arts, both during his time first at Stanford University, and now at Harvard, where he founded and is Faculty Director of metaLAB (at) Harvard. ${ }^{24}$

The UK and Irish contributions to the field of Italian Studies humanities computing and digital humanities has been substantially smaller than that of the States, yet can still claim some important and pioneering projects. Digital humanities work in Italian Studies in the British Isles has followed a very similar trajectory to the Italian and US cases, with specific Italian-studies oriented activities beginning in the 1980s, led primarily by early-adopter premodern Italian researchers working in universities with world-leading computing units, such as David Robey at Oxford in the 1980s, and the Italian department at Edinburgh in the early 1990s, with a marked expansion of activities and inter-institution collaboration from the later 1990s onwards. Robey obtained an early electronic text of Dante's Commedia for his computer-assisted metrical analyses, via the legendary female computing pioneer Susan Hockey's links with Antonio Zampolli at the Laboratorio di Linguistica Computazionale in Pisa; Robey's 2007 database for the analysis of medieval and Renaissance Italian metrics, Sound and Metre in Italian Narrative Verse is still online at $<$ http://www.italianverse.reading.ac.uk $>^{25}$ In Edinburgh, computational approaches were integrated into the research and teaching of both premodern and modern Italian literature, with Jon Usher and Guyda Armstrong using text concordancing software to explore concealed lexical patterns in works by Calvino and Machiavelli. ${ }^{26}$ The department was also at the forefront of research into the literary genetics of digitally-mediated literary texts, with the establishment of the Digital Variants database of contemporary Italian authors by Domenico Fiormonte and Jon Usher in $1996,{ }^{27}$ while Federica

\footnotetext{
${ }^{19}$ Conceived by Jennifer Hogan and developed in collaboration with Teodolinda Barolini, from 1994 onwards: https://digitaldante.columbia.edu/about-us/.

${ }^{20}$ Led by Hollander and launched in 1999: <http://etcweb.princeton.edu/dante/index.html $>$.

${ }^{21}$ Led by Massimo Riva, from 1994 onwards: < http://www.brown.edu/Departments/Italian_Studies/dweb/>.

${ }^{22}$ Led by Massimo Lollini, from 2003 onwards: < https://petrarch.uoregon.edu/history-project>.

${ }^{23}$ Led by Wayne Storey, from 2013 onwards: <www.petrarchive.org>.

${ }^{24}<$ https://metalabharvard.github.io $>$.

${ }^{25}$ For more information, see Robey's 'Counting Syllables in the 'Divine Comedy': A Computer Analysis', The Modern Language Review, 94.1 (1999), 61-86, and Sound and Structure in the Divine Comedy (Oxford: OUP, 2000). The Reading database (accessed 1 February 2020) contains narrative poems from Dante, Petrarch, Boccaccio, Pulci, Boiardo, Ariosto, and Tasso.

${ }^{26}$ Jon Usher, 'Calvino and the Computer as Writer/Reader', MLR, 90.1 (1995), 41-54, and 'From 'super-albero' to 'iper-romanzo': Lexical Continuity and Constraint in Calvino's Se una notte d'inverno un viaggiatore', Italian Studies, 51.1 (1996), 181-203; Guyda Armstrong, 'Computer-assisted literary analysis using the TACT text-retrieval program', Computers and Texts, 11 (1996), 8-11.

${ }^{27}$ Fiormonte completed what was probably the first humanities computing $\mathrm{PhD}$ in Italian Studies in the Edinburgh Italian department in 2003, with a thesis on 'Scrittura, filologia, e varianti digitali', unpublished doctoral thesis, University of Edinburgh, 2003. The Digital Variants website moved to Roma Tre, but no longer seems to be available.
} 
Pedriali pioneered electronic approaches to the study of Gadda, founding the online digital Edinburgh Journal of Gadda Studies in 2000, which continues to this day. ${ }^{28}$

The main UK-based Italian Studies digital humanities projects post-2000 have tended to focus on creating new electronic bibliographical resources for the Italian Studies research community, driven by the research councils' explicit aim to galvanise activity in this area, which have seen Italianist academics often working in partnership with national and/or university libraries. Notable projects of this type include the Italian Academies $1525-1700$ project $(2006-2009 ; 2010$ 2014), directed by Jane Everson (RHUL) and Lisa Sampson (Reading), which has created a catalogue of the British Library's holdings of Italian Academy material. ${ }^{29}$ Armstrong's Manchester Digital Dante project (2009-), initially funded by the British Academy, has created full digitisations of a number of culturally significant early printed editions of the Commedia held in the Special Collections of the University of Manchester's John Rylands Library, and continues to expand. ${ }^{30}$ In the past decade, the AHRC has funded two further major bibliographical database projects in premodern Italian. The Vernacular Aristotelianism in Renaissance Italy, c. 1400-c. 1650 (VARI) project (2010-2014) has mapped the Renaissance diffusion of Aristotelian works in the Italian vernacular in a powerful searchable catalogue of some 200 printed editions and 200 manuscript works. ${ }^{31}$ The Petrarch Commentary and Exegesis in Renaissance Italy, c.1350-c.1650 (PERI) project, (2017-2019) is currently building two large-scale digital resources for the study of Petrarch's early exegetical reception. These comprise a huge searchable database with details of hundreds of manuscript witnesses and printed editions of commentaries, lectures, and other modes of exegesis, and the world's first comprehensive early printed Petrarch digital library, comprising approximately 100 fully digitised editions of print editions from the fifteenth to the seventeenth centuries held in Manchester University's John Rylands Library, and the Hesburgh Library at Notre Dame University, USA, housed within the University of Manchester's new IIIF/TEI-XML image viewer $<$ https://www.digitalcollections.manchester.ac.uk/collections/petrarch/1>. ${ }^{32}$ In the modern period, the Dialectics of Modernity project, funded by the AHRC (2016-2018), meanwhile harnesses the online digital space to present a system of interconnected trajectories through cultural artefacts produced under Fascism, accompanied by data visualisations and a digital exhibition,

\footnotetext{
${ }^{28}<$ https://www.gadda.ed.ac.uk/Pages/aboutus.php $>$.

${ }^{29}$ The main project page is at: <http://italianacademies.org/about/>, while the database can be accessed at $<$ http://www.bl.uk/catalogues/ItalianAcademies/>. The datasets can be downloaded at: $<$ https://data.bl.uk/iad/ $>$.

${ }^{30}<$ https://manchesterdante.wordpress.com/about/ $>$. The first three digitised Dante editions also featured in the SCARLET Augmented Reality teaching project, along with several other iconic objects from the University's collections: <https://archiveshub.jisc.ac.uk/features/SCARLET/index.html $>$.

${ }^{31}$ The database can be consulted at $<$ https://vari.warwick.ac.uk $>$; and the original site (now deprecated) can still be accessed at: < https://warwick.ac.uk/fac/arts/ren/researchcurrent/vernaculararistotelianism/ $>$.

${ }^{32}$ The searchable database can be accessed at $<$ https://petrarch.mml.ox.ac.uk/about/ $>$.
} 
linked to an online open-access monograph. ${ }^{33}$ The emphasis in the UK has therefore been on resource curation and enhancement, and digital content creation, rather than the major-authorfocused one-stop-shop, or Italian department 'Lab' model, as seen primarily in the US, or the creation of huge networked Italian electronic literary resources and large-scale computational analyses of them, as found in Italy. Just as in Italy and the US, digital humanities activities tended to cluster in certain university centres, but for the most part, UK Italianist scholars (with a few exceptions) have tended to develop projects individually with their local technical teams, rather than working within larger university research groups or the departmental Italian studies lab models found elsewhere. They were, however, well-connected between themselves, which has led to key international collaborations and some mobility of individuals between the UK and leading Italian and North American Italianist research bases.

\section{The digital as 'object of study'}

As an interdisciplinary field, Italian Studies in the UK and Ireland has typically included the study of Italian language, literature, and culture, the latter encompassing a variety of artistic and nonartistic subjects such as cinema, theatre, visual arts, as well as history, politics and media. The intersection of Italian Studies and Media Studies, in particular, has proven to be particularly useful to analyse a broad area of media, including television, radio, advertisements, fashion, music industry and their interconnection in postmodernism, visual arts and cultural studies, while premodern book historians extend media theory and material culture approaches into their work on the media objects of the past. By combining a variety of critical approaches (such as semiotics, feminist theory, critical race theory, literary theory, communication theory, political theory, and Marxism), cultural studies has become one of the core methodological frames which has proven to be effective to understand how meanings are constructed, validated and disseminated in contemporary societies. In recent decades, digital convergence in the arts and creative industries has however introduced unprecedented social practices and technological processes, such as advanced programming, extensive digitisation, hypertextuality and hypermediation, interactivity and participation, virtuality and simulation, convergence and remediation, exposing scholars of Italian Studies to new epistemes and constellations of power relations in the cultural industries. New digital genres, such as electronic literature, web series, digital animation have emerged. New forms of mediation and narratives, such as micro-blogging, interactive and visual storytelling have become our main form of social communication. This transformation in communicative and artistic

\footnotetext{
${ }^{33}$ The website can be accessed at $<$ http://dialecticsofmodernity.manchester.ac.uk $>$; Francesca Billiani and Laura Pennacchietti, Architecture and the Novel under the Italian Fascist Regime (London: Palgrave Macmillan, 2019).
} 
practices has inevitably created a new 'object of study', ${ }^{34}$ leading to a re-assessment of our theories and methodologies for enquiry into Italian contemporary culture.

A number of seminal theoretical texts in media theory have thoroughly examined the profound transformations occurring in the epistemologies of representation, language, authorship, readership, textuality, narratives, becoming essential references in our reading lists. ${ }^{35}$ In our more familiar areas of languages, literatures and cultures, we have especially faced an 'expansion' of textualities across digital and non-digital platforms, ${ }^{36}$ which has resulted in an enhanced crisscrossing of arts and media. Rapidly expanding freedom of expression, on the other hand, has given rise to a variety of new cultural phenomena, ranging from enhanced bottom-up creativity to radicalised hate speech.

Intermediality studies, a relatively new discipline which started developing in the 1990s, has arguably played a crucial role in exploring the exchangeability of expressive means and aesthetic conventions between different art and media forms in the digital age. Interestingly, not only can we trace the roots of the first experiments in this field in the historical avant-gardes, such as Futurism and the Neo-Avant-Garde, but it was also in these same periods that theories of 'expanded' art - see, for example, Gene Youngblood's notion of 'expanded cinema' — $^{37}$, as well as theories of interart/intermedia were initially discussed. The concept of 'intermedia is, in fact, far from being a novelty: originally coined by Samuel Taylor Coleridge in On Edmund Spencer (1812) to refer to chemical agents who can fuse reality and symbols, it was popularised by Dick Higgins in his homonymous book Intermedia (1966) to describe the fusion between the different artistic languages; a condition which, in the age of 'postmedia', as theorised by Rosalind Krauss in $A$ Voyage on the North Sea (2000), has become even more common, if not the norm. ${ }^{38}$ Scholars such as Marie-Laure Ryan, Irina Rayewskij, Lars Elleström, Ágnes Pethö, and, in Italy, Massimo Fusillo, have offered some important contributions on intermedia theory, intermedia poetics, pictoriality

\footnotetext{
${ }^{34}$ The 'Digital as Object of Study' was one of the categories explored by Claire Taylor and Niamh Thornton in their position article 'Modern Languages and the Digital: The shape of The Discipline', Modern Languages Open, [n.p.] DOI: http://doi.org/10.3828/mlo.v0i0.156. Together with 'Big Data and Modern Languages', 'Modern Languages and Digital Archives', 'Digital Ethnography', 'Users and Interfaces', the 'Digital as Object of Study' is a flexible and open category which includes digital narratives, digitally born literature, digital genres, which constantly evolve with technologies.

${ }^{35}$ Key texts include Jay David Bolter and Richard Grusin, Remediation. Understanding New Media (Cambridge: The MIT Press, 1999); Lev Manovich, The Language of New Media (Cambridge: The MIT Press, 2001); Katherine Hayles, Writing Machines (Cambridge: The MIT Press, 2002); George Landow, Hypertext 3.0. Critical Theory and New Media in an Era of Globalisation (Baltimore: Johns Hopkins University Press, 2006), and Henry Jenkins' Convergence Culture. When Old and New Media Collide (New York: NYU Press, 2006).

${ }^{36}$ This is what Alberto Casadei includes in the description of what he calls the 'allargamento dello spazio letterario'. See Alberto Casadei, Letteratura e controvalori, critica e scritture nell'era del web (Rome: Carocci, 2002), p. 130.

${ }^{37}$ Gene Youngblood, Expanded Cinema (New York: Dutton, 1970).

38 Dick Higgins, 'Intermedia', The Something Else Newsletter, Vol. 1, n.1, February 1966 $<$ http://www.primaryinformation.org/oldsite/SEP/Something-Else-Press_Newsletter_V1N1.pdf $>$; Rosalind Krauss, ' $A$ Voyage to the North Sea': Art in the Age of the Post-Medium Condition (New York: Thames and Hudson, 2000).
} 
across media, literature in-between media; intermediality in video games; intermediamorphosis, transmedia narratology, and digital interaction, to mention only a few areas. ${ }^{39}$

Although many of these artistic practices have thus existed for centuries - and Wagner's Gesamtkunstwerk (total work of art) represents one of its most significant examples - digital convergence has called for a reassessment of the interrelation between arts and media. ${ }^{40}$ As Fusillo rightly pointed out in his definition of 'Intermediality' for the Treccani encyclopaedia, 'Oggi il cyberspazio può considerarsi per certi versi una realizzazioni tecnologica dell'opera d'arte totale, in cui i diversi linguaggi artistici si combinano e si rimediano continuamente' ${ }^{41}$ The analytical tools and terminology of intermediality studies have proven to be particularly helpful when it comes to examining digital and hybrid genres such as a combination of arts, socio-technical processes and digital platforms. Some broad categories, such as 'media transposition', 'media combination' and 'intermedial reference' help us identify the type of relationships occurring between media, as well as the different material elements and social dynamics which compose individual hybrid artistic works and practices. Which arts, processes and platforms are involved in this unique artwork or artistic practice? How are they creatively used to develop a narrative, an aesthetic experience, ultimately a meaning? How are power relations articulated in this new media scenario?

Digital convergence has not only introduced new cultural paradigms, but also new epistemologies. In Italian Studies, a number of new research areas have developed to address the intermedial relationship between literature and electronic media (analogue and digital), with a special focus on electronic literature and hybrid narrative objects, such as blooks lit-blogs and Twitteratura. In this respect, an increasing interest has also developed in early forms of experimentation between electronic media and literature, such as those by Nanni Balestrini, Gianni Toti, and Caterina Davinio, looking at the evolution of these hybrid forms in conjunction with

\footnotetext{
${ }^{39}$ See, for example, Marie-Laure Ryan, 'Transmedial storytelling and transfictionality', Poetics Today, 34(3), 361-388; Lars Elleström, The Modalities of Media: A Model for Understanding Intermedial Relations', in Media Borders. Multimodality and Intermediality, edited by Lars Elleström (Basingstoke: Palgrave, Macmillan, 2010), pp. 11-48; Agnes Pethö, Cinema and Intermediality. The Passion for the In-Between, (Cambridge Scholars Publishing, 2011); Irina Rayewski, Intermedialität, (Tübingen/Basel: Francke, 2002); Massimo Fusillo, 'Intermedialità' [http://www.treccani.it/enciclopedia/intermedialita \%28Enciclopedia-Italiana\%29/]; Massimo Fusillo, 'Estetica del pastiche e intermedialit.: .Povera piccina', Chi ride ultimo. Parodia satira umorismi, Eds. E. Abignente, F. Cattani, F. de Cristofaro, G. Maffei, U. M. Olivieri, Between, VI.12 (2016), <http://www.betweenjournal.it/>.

${ }^{40}$ This is not an entirely new method in the arts. For example, in 1971, Christian Metz applied the first intertextual approach to filmic text, claiming that cinema is a combination of specific codes which constitutes the peculiarity of cinema and other languages which cinema shares with other media. What such a convergence produces is a series of semiological interferences which require an 'intersemiotic translation' (such as borrowings, imitations, adaptations). A certain comparison can be drawn between the convergence of different artistic languages in cinema and in the digital age which, as Lev Manovich aptly remarked, presents various similarity with the language of new media. See Christian Metz, Language and Cinema (The Hague-Paris: Mouton, 1974).

${ }^{41} \mathrm{http}: / /$ www.treccani.it/enciclopedia/intermedialita_\%28Enciclopedia-Italiana\%29/
} 
technological advances in IT and experiments of remediation. ${ }^{42} \mathrm{~A}$ second area has been transmediality, namely the transposition of various forms of narratives, such as literary or filmic stories, memory, history, as well as the transposition of more discrete elements of storytelling, such as motifs, themes, characters. We will illustrate both areas in the next two sections.

The exploration of the intersection between the Italian arts and digital media has been precisely one of the research areas of the AHRC-funded project Interdisciplinary Italy 1900-2020: interart/intermedia (2015-2020). ${ }^{43}$ Crucially, the analysis of the cultural panorama of digital media requires new interdisciplinary theoretical frameworks, methodologies and critical tools: how do we analyse these new forms of textuality and assess their cultural value? What narrative theories and aesthetic approaches do we need in order to understand the expansion of stories across multiple media? What methodological approaches can help us unravel the significance of various digital genres? What is national and transnational about Italian digital culture? And how can we use digital methods to creatively approach and critically reflect on the digital as 'object of study' with our students?

\section{Intermediality: when Italian literature meets computers}

The literary world has been deeply transformed by the digitisation of texts and/or their metamorphosis into hypertexts, hypermedia and other digital formats, as well as by the widespread diffusion of the Internet in society. Novels and poetry have become readable and portable in different formats and devices beyond the book - for example, on ebook, mobile phones, Ipads, and laptop screens. ${ }^{44}$ Thanks to the Internet and social media, stories and verses travel across multiple media platforms, undergoing different medial transpositions and presentation forms such as a multimedia novel or poem, Twitter fiction, collaboratively written narratives. When they are simply digitised from an originally printed text and transferred to a digital platform, they still lend themselves to different forms of fruition and interaction. Not only have the boundaries between authors and readers blurred, but various forms of participation have been generated from their interaction, especially in the social media age. Users can interact with the author and the text in different ways, but they can also interact with each other, by commenting or co-writing a story. ${ }^{45}$

\footnotetext{
${ }^{42}$ As discussed above, this was also a point of reflection in the $1990 \mathrm{~s}$, in the second wave of Italian Studies humanities computing projects such as Jon Usher's studies of Calvino using text analysis software.

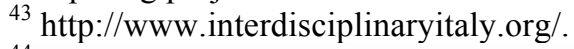

${ }^{44}$ See Gino Roncaglia, La quarta rivoluzione, sei lezioni sul futuro del libro (Bari: Laterza, 2010).

${ }^{45}$ Another crucial transformation in the literary world is 'disintermediation', namely which has significantly affected the way we understand authorship, the interactions between authors and readers, but also in how fandom and other activities related to writing influence the 'symbolic value' of authorship. In some cases, this has ended up being strongly affected by social networks' popularity. For example, leading newspapers such as Repubblica or Corriere della
} 
When the first examples of hypertext fiction appeared, they were considered as the ultimate form of avant-garde or postmodern experimentation in literature, ${ }^{46}$ in which poststructuralist literary theory and information theory converged. ${ }^{47}$ Similar impulses were contemporaneously present in scholarly digital humanities projects, such as for the Decameron Web project, which began as a hypertext experiment in narrative construction. A few years later, social media triggered the development of a wide range of 'new narratives', including micro-blogging, collaborative writing, visual storytelling on Instagram. Writing with constraints, in groups, and mixing words and images, is, again, far from being a novelty, since these practices were at the core of avant-garde experimentation in the twentieth century. Yet, digital technologies have opened this up for everyone. There has been, consequently, an increasing interest in how digital genres and experimental narratives developed in the digital age are informed by both national and international cultural background. ${ }^{48}$

Overall, scholars of contemporary literature have been more reluctant to consider hybrid digital genres such as digital poetry or hypertext novels as 'literature'. This is especially due to the fact that, in Italy, as in other countries, there is still a strong literary tradition, and more rigid disciplinary boundaries often exist between literary and media studies. Most of the Italian critical studies on the relationship between literary writing and digital storytelling published in the last twenty years have been written, in fact, by scholars in sociology of literature, media studies and semiotics, and their arguments often reflect the tension between these disciplinary fields and the field of Italian Studies. ${ }^{49}$ In the field of contemporary Italian literature, early theoretical debates

sera and other traditional media such as radio and TV tend to give space to figures who have gained popularity on social networks. The phenomenon is also noticeable in publishing houses: for marketing purposes, the cross-fertilisation between writers and social networks has grown. Not only can we find examples of books which were originally born as Facebook posts, but we can also notice how publishers' choices tend to be influenced by writers' popularity on social networks.

${ }^{46}$ See, for example, Da Calvino agli ipertesti, edited by Simona Storchi and Laura Rorato (Firenze: Cesati, 2002).

${ }^{47}$ As argued by George Landow, hypertexts expressed the dream of poststructuralist theory in terms of the death of the author (Roland Barthes), appropriation and writing difference (Derrida). See George Landow, Hypertext 3.0: Critical Theory and New Media in an Era of Globalisation (Baltimore: Johns Hopkins University Press, 2006)

${ }^{48}$ See two guest-edited issues of Comparative Critical Studies, 13.3 (2016) and Romance Studies, 16.1 (2016), edited by Emanuela Patti, include a selection of papers from this conference.

${ }^{49}$ To mention just some examples: Alberto Abruzzese and Isabella Pezzini, Dal romanzo alle reti (Rome: Testo e immagine: 2004), Gabriele Frasca, La lettera che muore (Bologna: Luca Sossella, 2005); Alberto Abruzzese and Giovanni Ragone (eds), Letteratura fluida (Napoli: Liguori, 2007), Agnese Camillini, Dal romanzo alle reti. La scrittura digitale come forma romanzo (Rome: Aracne, 2007), Arturo Mazzarella, La grande rete della scrittura (Torino: Bollati Boringhieri, 2008); Mario Gerosa, Parla come navighi. Antologia della webletteratura italiana (2010), Massimo Riva, Il futuro della letteratura. L'opera letteraria nell'epoca della sua (ri)producibilità digitale (2011) and Pinocchio Digitale. Post-umanesimo e Iper-romanzo (Milan: Franco Angeli, 2012). While these works were not specifically concerned with Italian case studies, they raised crucial questions about the effect of the Internet and digital technologies on narratives, with special attention to the friction between the literary world and the web. More recently, an edited volume and a monograph have taken into consideration Italian case studies with a more specific focus on the social media age: Francesco Giusti, Damiano Frasca, Christine Ott (eds), Poesia e nuovi media (Milan: Franco Angeli, 2018); and Paolo Massari, Letteratura e nuovi media. Come la scrittura cambia dimensione (Rome: Bulzoni, 2018) 
revolved instead around the impact of the Internet and digital technologies on criticism, following up on what had been perceived as the 'crisis' of Letters. ${ }^{50}$ Lit-blogs, namely blogs specialising in literature but also broader cultural issues, have offered alternative platforms for critical debates and scholarly discussions on literature, cinema, theatre and other arts. Between 2006 and 2011, especially, they revitalised what was in fact a typical Italian tradition of impegno, started by Vittorini, Calvino, Pasolini, and the neo-avant-gardist Gruppo 63, which played out in the literary journals. In their early days, lit-blogs filled a gap in the literary world of the 1990s, due to the crisis of what was traditionally known as 'militant criticism'. Literary columns in newspapers seemed to have become merely functional to publishing houses, insofar as they mainly oriented readers' tastes, ultimately guiding readers towards the purchase of books. On the other hand, academia appeared to many writers and critics to be more and more self-referential. ${ }^{51}$ Lit-blogs thus were able to claim a space for 'critical autonomy', especially in the early years. They also gave voice to a certain marginality, often originating from underground cultures. A 'first wave' of lit-blogs, ${ }^{52}$ including Carmilla (1995), Nazione Indiana (2003-), Lipperatura (2004-), Vibrisse (2004-), Il primo amore (2006-), La poesia e lo spirito (2006-), ${ }^{53}$ thus strongly relied on the utopia of 'democratisation' and 'freedom of speech' which was associated with the Internet between the 1990s and the first decade of the Millennium. They were also characterised, as Emanuele Zinato claims, by two distinctive features: spontaneismo and invettiva, ${ }^{54}$ which, in some cases, found inspiration from Pasolini's myth of parrhesia.

In a 2015 article, 'Impegno 3.0. Towards participatory criticism?', Pierpaolo Antonello raised a number of critical points related to the notion of impegno in relation to the new media

\footnotetext{
${ }^{50}$ See, for example, Alberto Cadioli, Il critico navigante. Saggio sull'ipertesto e la critica letteraria (1998); 'Blog e letteratura', Nazione Indiana (2008), https://www.nazioneindiana.com/2008/12/03/blog-e-letteratura/; Giulia Iannuzzi, L'informazione letteraria nel web. Tra critica, dibattito, impegno e autori emergenti (2009); Gian Carlo Ferretti and S. Guerriero, Storia dell'informazione letteraria in Italia dalla terza pagina a Internet. 1925-2009 (2010): Emanuele Zinato, Le idee e le forme. La critica letteraria in Italia dal 1900 ai giorni nostri (Rome: Carocci: 2010); Francesco Guglieri and Michele Sisto, 'Verifica dei poteri 2.0. Critica e militanza letteraria in Internet', Allegoria (1999-2009) (2010), 153-74 <https://www.allegoriaonline.it/index.php/i-numeri-precedenti/allegoria-n61/11-il-presente/6165/62verifica-dei-poteri-20-critica-e-militanza-letteraria-in-internet-1999-2009>; Gilda Policastro, Polemiche letterarie. Dai Novissimi ai lit-blog (2012), Alberto Casadei, Letteratura e controvalori. Critica e scrittura nell'era del web (2014).

${ }^{51}$ A number of volumes written by prominent Italian critics describe this identity crisis of literature at the turn of the Millennium: Cesare Segre, Notizie della crisi (Turin: Einaudi, 1993), Giulio Ferroni, Dopo la fine. Sulla condizione postuma della letteratura (Turin: Einaudi, 1996); G. Ferroni, Scritture a perdere (Bari: Laterza, 2010); Mario Lavagetto Eutanasia della critica (Turin: Einaudi, 2005).

${ }^{52}$ Some of them were originally born as bulletins or newsletters. See, for example, this interview to Giulio Mozzi http://www.wuz.it/intervista-libro/5096/Intervista-Giulio-Mozzi.html.

${ }^{53}$ Other blogs created between 2006 and 2009 include Bookcafé by Giuseppe Granieri, Letteratitudine by Massimo Maugeri (2006-), Sul romanzo by Morgan Palmas (2009), Booksblog.

${ }^{54}$ Emanuele Zinato, Le idee e le forme. La critica letteraria in Italia dal 1900 ai nostri giorni, (Rome: Carocci, 2010), p. 208.
} 
landscape of the digital age. ${ }^{55}$ First, Antonello highlights that the effectiveness of literary, artistic and political communication on readers/audiences has rarely been a concern, when we talk about impegno, recognising that authorial intentions have often ended up in being either self-referential or have targeted a rather homogenous political audience. Second, whether communicative effectiveness is simply a form of emotional response, desire and identification from the audiences' part, rather than a rational assessment of the ideology underpinning a work of art is another important question. Arguably, both points are extremely relevant when we reassess impegno in digital platforms. Criticism has been significantly transformed by blogging, leading to interconnectivity on a massive scale, and new collaborative forms. The typical hierarchical structure of traditional gatekeepers has been replaced by a more horizontal 'interpretative activism' which has introduced some progressive stances. ${ }^{56}$ Yet, to what extent is the democratisation of criticism sustainable and truly progressive? Maybe, we should just think of it as a practice rooted in traditional writing and printing which blogging has tried to imitate and remediate in its first two decades of life. In the conclusion, Antonello signals the crucial role that digital humanities will have in this respect. Indeed, whether 'critical digital humanities' will be the new form of impegno is one of the big questions we need to urgently address, as we discuss further in the conclusion of this article.

\section{Transmediality: When Stories Travel Across Media}

In the last decade, a number of contemporary writers or groups, such as Wu Ming, Giuseppe Genna, Tommaso Pincio, Kai Zen, and Scrittura Industriale Collettiva-have attempted to expand narratives beyond the book object in various forms of experimentation. Transmediality was in fact one of the key points raised in the Memorandum of the New Italian Epic (2009), a document written by Wu Ming, with the collaboration of readers' critical interventions, which mapped some common trends in a number of Italian novels produced in the first decades of the new Millennium. The Memorandum emphasised how most of these novels, also renamed by Wu Ming as 'unidentified narrative objects' (UNO) [oggetti narrativi non identificati], ${ }^{57}$ developed their narratives across

\footnotetext{
${ }^{55}$ Pierpaolo Antonello, 'Impegno 3.0. Verso una critica partecipativa?', Between, 10 (2015), special issue 'L'immaginario politico. Impegno, resistenza, ideologia', ed. by S. Albertazzi, F. Bertoni, E. Piga, L. Raimondi, G. Tinelli, <www.betweenjournal.it>.

${ }^{56}$ See Peter Stamatov, 'Interpretive Activism and the Political Uses of Verdi's Operas in the 1840s', American Sociological Review, 67.3 (2002), 345-66.

${ }^{57}$ See <https://web.archive.org/web/20090301002806/http://carmillaonline.com/archives/2008/09/002775.html>; Kate Willman has extensively analysed these 'unidentified narrative objects' in her recently published book Unidentified Narrative Objects and the New Italian Epic (Oxford: Legenda, 2019).
} 
multiple media, crossing borders between arts, communication practices, styles, genres, and so on. Not unexpectedly, Wu Ming, who promoted the discourse in this direction, had engaged with Henry Jenkins' work in both theoretical and practical terms: they wrote the foreword of the Italian edition of Convergence Culture and applied some of its theories to the textual expansion of their novel Manituana (2007) on the dedicated website. This supported the experiment of Manituana as an 'open work' at multiple levels: for example, as fan fiction, readers could continue the story or rewrite some parts in a special section; as extra multimedia materials, such as maps, images, music, related live events, the imaginary of the story was reinforced through visuals, sounds, graphic elements, performances. This was just the beginning of a creative use of Web 2.0 by writers. ${ }^{58}$ Roberto Saviano is another excellent example of how both authorship and narrative (Gomorra) can transmediate and manifest in different variants across multiple media, still symbolically holding together one single 'culturally-loaded figure'. Through a versatile transformation across media, Saviano's personal journey into the international empire of Naples' organised crime system acquires the features of what Giuliana Benvenuti has defined as the 'Gomorra brand' in a recently published book, Il brand Gomorra. Dal romanzo alla serie TV (2018): a glocal distributed narrative of Camorra which spreads across television, cinema, theatre, radio, web series, social networks, and possibly video games in the near future. ${ }^{59}$

In the case studies above, some of the stories are based on fiction, others are supposedly based on historical facts or identity construction, but they all expanded across multiple media, whether fiction, cinema, TV, blogs, social networks, radio, newspapers. Arguably, social media, as mass media, play a crucial role in the development of imaginaries and they do it in new powerful ways. They have questioned the notion of authorship, author-readers relationship and textuality beyond what had already been theorised by George Landow in his Hypertext 3.0. Collaboratively written narratives, for example, have been facilitated by digital platforms such as wikis and blogs. The experiment of the collaboratively written novel In territorio nemico by Scrittura Industriale Collettiva proves that 115 professional and non-professional writers can co-write a story based on first-hand experience and fictional memories. How popular icons emerge in the digital age is certainly an area which requires more attention in Italian Studies, as we will elaborate in the final section of this article. Class categories we used to address culture, namely 'highbrow', 'middlebrow', 'lowbrow', need to be re-assessed in the light of bottom-up practices which tend to be re-mixed in new ways. As mentioned above, the extensive digitisation of media texts has

\footnotetext{
${ }^{58}$ See Transmedia. Storia, memoria e narrazioni attraverso i media, ed. by Clodagh Brook and Emanuela Patti (Milan: Mimesis, 2014).

${ }^{59}$ Giuliana Benvenuti, Il brand Gomorra. Dal romanzo alla serie TV (Bologna: Il Mulino, 2018). On the dynamics of global media and entertainment see Paolo Sigismondi, The Digital Glocalization of Entertainment: New Paradigms in the 21st Century Global Mediascape (New York: Springer, 2012).
} 
enhanced post-modern practices of hybridisation between high and low culture. How meanings are created in the digital space and between the digital space and external environments is thus another frontier in digital cultural studies.

In Italy, some of these lines of research in intermediality and transmediality in the digital age have been addressed in the area of comparative literature, as this has typically investigated, among other topics, the relationship between literature and other arts and media. For example, three recent special issues of Between, the journal of the Italian society for comparative literature (Compalit), have respectively explored the intersections between digital technologies, storytelling, imaginary; literature and screens (as both metaphors and material devices); and fictions across media. ${ }^{60}$ These issues mainly take into consideration non-Italian case studies. Yet, they tackle theoretical and methodological questions about transmediality in interesting ways.

\section{Towards Italian digital culture studies}

The panorama we have outlined in this article broadly covers the period which is now commonly known as the Digital Revolution, or Third Industrial Revolution. ${ }^{61}$ We have tried to weave together some of the disparate threads of trends and genealogies which bring us to the present moment of digital humanities and digital culture studies, which encompass, on the one hand, a rather fragmented scenario of projects in Italian Studies and digital humanities produced in different geographical locales from the 1980s to the present day; on the other hand, a series of emerging areas of study exploring intermedia and transmedia practices across the Italian arts and digital platforms, which has historically also intersected with scholarly computing at various points. This article has highlighted the main research areas in which digital technologies have transformed Italian Studies during the Digital Revolution. We have now entered the so-called Fourth Industrial Revolution, where physical, digital and biological spheres converge in even more advanced ways, and the fifth one (Society 5.0), as recently announced at the World Economic Forum, seems to be almost upon us. The widespread use of mobile technologies and the increased ubiquity and pervasiveness of Artificial Intelligence in our daily lives urgently calls for a systematic analysis of how Italian Studies can respond to this radical transformation in terms of artistic, cultural, social,

\footnotetext{
60 'Tecnologia, immaginazione, forma del narrare' (2015), ed. by Emanuela Piga, Lucia Esposito and Alessandra Ruggiero; 'Screens. Representations, images, transmediality' (2018), ed. by Francesca Agamennoni, Matteo Rima, Stefano Tani; and 'Fictions, truths, lies, possible worlds' (2019), edited by Rosalba Galvagno, Maria Rizzarelli, Massimo Schilirò, Attilio Scuderi.

${ }^{61}$ This concept was popularised by Jeremy Rifkin, The Third Industrial Revolution: How Lateral Power is Transforming Energy, the Economy, and the World (Basingstoke: Palgrave Macmillan, 2011). See also Klaus Schwab, The Fourth Industrial Revolution (London: Penguin, 2017).
} 
political and educational practices. ${ }^{62}$ There are undoubtedly other areas of intersection between digital technologies and, for example, Italian society, politics, or philosophy, which would contribute to a more systematic reconstruction and analysis of Italian culture during the Digital Revolution(s). Crucially, social media have also created new 'circuits of culture', where avantgarde, highbrow culture, and mass media cultures mix in new forms of 'digital popular cultures', sometimes revealing inevitable frictions. And we should not forget that at the same time, the products of historic 'high culture', our former analogue objects of study, (i.e. the digitisations of artefacts held in libraries, museums and galleries) are contained in and circulate via the self-same digital media channels as born-digital materials.

How, then, can we integrate digital tools with digital texts, and integrate them with our historically analogue work? As a discipline we should seek ways and methodologies to turn the same critical gaze on all our digital artefacts, media, and practices as they permeate our scholarly landscape, and use this awareness explicitly to build an interdisciplinary, trans-national, and transtemporal understanding of the Italianist mediascape. One possible line of action might be to engage more self-consciously with all the digital dimensions of the cultural artefact, making visible the layers of representation inherent in each digital object, and reading the digital container and its interface, networked infrastructure, and the language of the code itself as representations and expressive forms in and of themselves; another would be to address ourselves more explicitly to the politics of the digital, and use it as a way into a renewed intellectual impegno and collective academic activism.

This debate has in fact played out over the past few years in digital humanities with regard to global and local definitions and identities. The Italian scholar Domenico Fiormonte, in particular, has been instrumental in articulating a critique of Anglo-American dominance of the field of digital humanities and its structures and practices. ${ }^{63}$ He notes that, despite its long history and longstanding institutional presence, 'Informatica umanistica, like most of the other $\mathrm{DH}$ practiced in the world, practically does not exist', and accordingly, argues for a digital humanities in which the (Anglosphere) centre cultivates the peripheries, working consciously to identify and then counteract

\footnotetext{
${ }^{62}$ A number of factors are at play here. Firstly, the global nature of networked society sometimes leads to the assumption that its paradigms go precisely against any national cultural discourse. Secondly, due to the economic power of the computing megacorporations of Silicon Valley, including Microsoft, Google, Amazon and Netflix, digital culture has often been largely treated as an Anglo-American phenomenon of cultural importation. Hundreds of volumes have been published on digital culture and its constantly evolving subcategories — from virtual reality to social networks, but very few, so far, have considered the impact of digital technologies on local, regional and national territories, especially in the artistic domain.

${ }_{63}$ Domenico Fiormonte, 'Towards a Cultural Critique of the Digital Humanities', Historical Social Research/Historische Sozialforschung, 37.3 (2012), 59-76; Domenico Fiormonte, Teresa Numerico, and Francesca Tomasi, The Digital Humanist: A Critical Enquiry, trans. by Desmond Schmidt and Christopher Pearson (Brooklyn, NY: Punctum, 2015), esp. the last chapter, 'Conclusions: DH in a Global Perspective', pp. 207-218. The book can be viewed and downloaded at archive.org: $<$ https://archive.org/details/TheDigitalHumanist/page/n3 $>$.
} 
the deeply entangled exclusionary constructs of the institutional structures which govern national and international research cultures, but also those built into the digital tools and technologies, for example, 'the cultural and political problem (e.g. social networks) almost exclusively produced in the Anglo-American environment, and [...] the cultural-semiotic problem of the different tools of representation: from the icons of the graphical interfaces to the Unicode standards'. ${ }^{64}$ Risam enlarges this debate in her 2019 book New Digital Worlds: Postcolonial Digital Humanities in Theory, Praxis, and Pedagogy, noting 'at stake in this matter is who has control over world making in digital humanities, establishing the shape and boundaries of the global landscape, which in turn influences the practices that are integral to developing the digital cultural record' ${ }^{65}$ The structural geopolitical biases of 'world' digital humanities institutions forcefully replicate the hierarchies of the Global North and the Global South, and Risam proposes to replace this conventional centreperiphery model instead with a rhizomatic diaspora model, which better models the knowledges scattered between different 'national contexts, local scholarly practices, and overlapping histories of the digital humanities'. ${ }^{66}$ Moreover, for Risam, 'postcolonial digital humanities is grounded in a definition [...] that offers an expansive approach to the digital cultural record', and it is therefore aligned with both David Berry's 'critical digital humanities', and contemporary digital creative cultures as they are locally produced, and which have also been discussed in this article. ${ }^{67}$

It is this new critically inflected digital humanities which offers the most exciting ways forward for digital Italian studies: a conceptual space in which the digital representations of the 'Italian' cultural record which are so often the object of our study are themselves problematised and read within the media forms and structures which produce them, and seen as one element within the digital mediascape along with other electronic screen-based cultural and artistic productions. Rather than the digital being simply the domain of what we might term the 'digital canonical humanities', of prestigious research-council funded re-presentations of cultural monuments (and especially those relating to the tre corone and the Renaissance), we can instead aspire to a dispersed and dehierarchised connected digital collectivity, which elevates other voices and facilitates an explicit activist engagement of co-production. ${ }^{68}$

\footnotetext{
${ }^{64}$ Fiormonte, 'Towards a Cultural Critique', p. 62.

${ }_{65}^{65}$ On this, see Risam, chapter 3, 'Remaking the Global Worlds of Digital Humanities', pp. 65-87 (p. 65).

${ }^{66}$ Risam, pp. 74-75 (p. 75).

${ }^{67}$ Risam, pp. 7, 9.

${ }^{68}$ Risam, p. 16.
} 